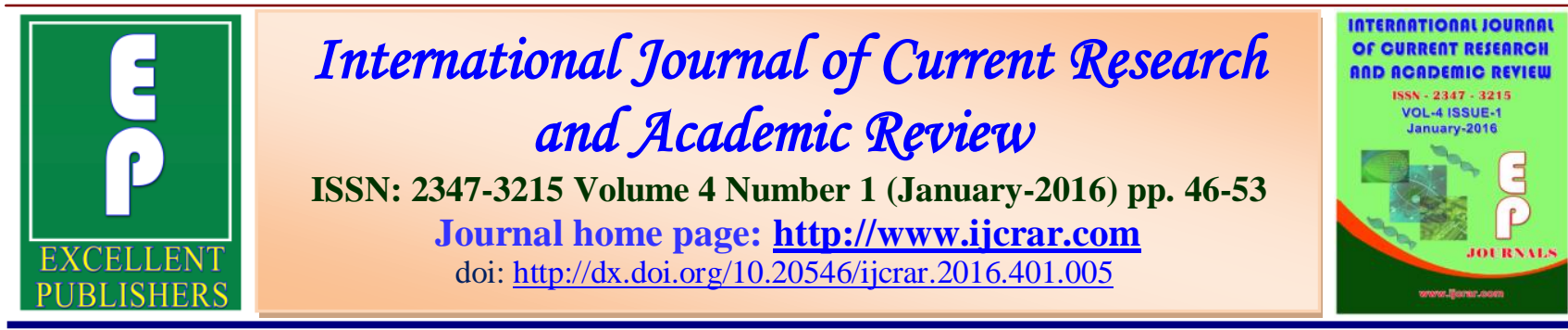

\title{
Rice Lines Performance Evaluation under irrigated conditions in the Senegal
}

\section{T. Guèye* and N. Saliou}

Ecole Nationale Supérieure d'Agriculture (ENSA), BP 296A, Thies, Senegal

*Corresponding author

\begin{tabular}{|c|c|}
\hline KEYWORDS & A B S T R A C T \\
\hline $\begin{array}{l}\text { Rice, } \\
\text { Lines, } \\
\text { Irrigation, } \\
\text { Traits, } \\
\text { Locations }\end{array}$ & $\begin{array}{l}\text { Over the two cultivated rice species, Oryza glaberrima Steudt. is a source of } \\
\text { useful genes for important traits that do not exist in Asian rice which belong } \\
\text { to species Oryza sativa L. This resistance gene deficiency in Asian rice has } \\
\text { limited his performance in Africa. This has greatly inspired interspecific } \\
\text { hybridization process between the two cultivated rice species in order to } \\
\text { promote a new type of rice better adapted to constraints and production } \\
\text { conditions of African farmer. To improve genetic diversity of rice grown in } \\
\text { irrigated conditions, performance evaluation of } 31 \text { intra- and inter-specific } \\
\text { lines was carried out on two sites for two seasons. Analysis of variance on } \\
\text { combined site and season showed significant Genotype effect on all } \\
\text { characters studied. Significant effect of Season on Plant duration and } \\
\text { interaction Genotype x Location (G x E) on Plant height was observed. No G } \\
x \text { E effect on grain yield was observed. Overall average Grain yields vary } \\
\text { between } 6.6 \text { and } 8.8 \mathrm{t} \text { ha }{ }^{-1} \text {. Positive correlation between Plant height and } \\
\text { Grain yields was observed and higher Grain yields were obtained by medium } \\
\text { to long duration lines. Based on average yields on Locations and Seasons } \\
\text { combined or not, three groups of lines were observed. }\end{array}$ \\
\hline
\end{tabular}

\section{Introduction}

Irrigated rice in the Senegal River Valley is intensive agriculture whose potential is not yet exploited optimally. It has the advantage of being free of the major fungal diseases (blast), bacterial or viral (RYMV). The availability of water of the river during all the year, allows the practice of double cropping with rainy season and dry season (Sié et al., 1998, Dingkuhn et al., 1995).
Farmers in this region can harvest twice a year (Dingkuhnn and Miezan, 1995). To effectively achieve this double cropping, which will contribute to increase food production through increasing frequency of crops ( $\mathrm{Hu}$ and al. 2015), it is necessary to sow medium and or long duration variety in rainy season and short duration variety in dry season. However various constraints 
exist, including low temperatures during dry season which tend to lengthen the cycle, Salinity / alkalinity of Delta lands (Asch et al., 1995), weed pressure (Diallo and Johnson, 1995), pest pressure (stem borers, defoliators and sucking sap), weakness of agricultural mechanization, low genetic diversity of cultivated varieties (Dingkuhn and Miezan 1995; Miezan and Sié., 1995; et al 1999 Ngam ), non-systematic use of seeds selected by a large segment of producers, non-compliance with technical itineraries, and socioeconomic conditions that limit rice production in the valley. Average yields in most developed areas, are around $5.5 \mathrm{t}$ ha- 1 . These yields are obtained on varieties Sahel 108, Sahel 201 and Sahel 202, which are the three main varieties cultivated in most areas developed in the region. They come from the collection of IRRI and were included in the varietal catalog Senegal since 1994, following various evaluation tests. Since then they have gradually replaced many of the old varieties introduced as IR8, D 52-37, KSS, and IKP JAYA, become increasingly rare or nonexistent for some of them. Five (5) other varieties including two short cycles and three cycles means, recently approved, are diffusion phase. These varieties have in common their Asian origin, and have a high sensitivity to adverse conditions of African ecosystems.

The search for more resistant varieties and better adapted to local socioeconomic conditions and constraints of the medium has become, over the past ten years, a major goal, in a context of recovery of national production. The interspecific hybrid development that combine the best features of the African cultivated rice, OryzaglaberrimaSteudt., More suited to local conditions, and Asian rice, Oryza sativa L., higher yielding obeys this strategy (Jones et al., 1997). Testing recombinant inbred lines is important in the process of creating new varieties (Li et al., 2015). As with other rice-growing ecosystems, Genotype, and Environment ofproduction are key factors that influence grain performance (Liang et al., 2015).Following a crossing program, fertile recombinant strains were obtained after several generations of backcrossing. The objective of this study is to test behavior of intra- and inter-lines, to identify promising genotypes well adapted to irrigated ricesytem in West Africa.

\section{Materials and Methods}

Plant material is comprised of 35 inter- and intraspecific varieties and lines including 4 controls. Entries were planted in rows in a randomized block design with 2 replications. Distance between lines and inside the linesis $20 \mathrm{~cm}$. Elementary plots are $4 \mathrm{~m}$ long and 3 $\mathrm{m}$ wide, i.e. an elementary area of $12 \mathrm{~m}^{2}$. Fertilization with urea and the DAP with the formula 120-60-60 (N, P2O5, K2O) was used. Phosphorus and potassium were made in cross transplanting and nitrogen as urea coverage in 3 applications: Early tillering $(40 \%)$, panicle initiation (40\%) and upstream migration panicle $(20 \%)$. Propanil herbicide treatment at a dose of 8 liter perhectare was used for the first weeding. Manual weeding followed depending on infestation. Four variables traits were measuredincluding plant duration from sowing to maturity $(\mathrm{M})$, plant height $(\mathrm{H})$, number of panicles per $\mathrm{m}^{2}(\mathrm{P})$ and grain yield (Y). The tests were conducted in 2004 during two successive seasons in 2 locations,Ndiaye and Fanaye, which are 115 $\mathrm{km}$ wide. Statistical analysis was made with the software Plant Breeding Statistics (PLABSTAT) (UTZ, 1997).

\section{Results and Discussion}

Average values of traits studied by season are summarized in Table 1. 
In rainy season, analysis of variance in Fanaye location showed significant difference between varieties and lines for characters plant duration from semi to maturity, grain yield, and plant height, and no significant effect for number of panicles per $\mathrm{m} 2$.

In dry season, varieties have a highly significant difference for all characters. In addition, plant duration and plant height and number of panicle per $\mathrm{m} 2$, have higher average values in dry season compared to rainy season.

In Rainy season in Ndiaye location, genotypes have a weakly significant difference for grain yield and highly significant effect for plant duration, plant height and number of panicle per quadrate meter (Table 2). In dry season the difference between varieties and lines is highly significant for all variables. As for the site Fanaye, the average value of measured traits in Ndiayelocation was also higher in dry season than in rainy season.

The average values of the measured variables combined on both sites are summarized in Table 3 . In rainy season as dry season varieties and lines showed significant differences for all variables.

The average value of variables studied, combined on both sites and both seasons, is summarized in Table 4. There is a highly significant difference for all the traits studied.

All $\mathrm{F}$ values for season, location, genotype and their interactions are summarize in table 5 .

$F$ values of analysis of variance showed a highly significant difference of genotypes for all traits studied. A significant effect of season on Plant duration and interaction genotypes $\mathrm{x}$ location on plant height was also noted. Interaction genotype $\mathrm{x}$ location has a weakly effect on plant duration. Combined effect Genotype x Environment x Season on grain yield is also weakly. There was no Genotype x Environment effect on grain yield.

Figure 1 shows distribution of lines according to plant duration and grain yield.

Lines are divided into three different plant duration (short, medium and long). Earliest lines are found in intraspecific progenies such as WAS173-BB-9-5, WAS196-B-4-3 and WAS173- BB-6-4, with 112.88, 113.25 and 113.38 days after sowing respectively (Figure 1 and Table 3).

There is a positive correlation between plant duration and grain yield $\mathrm{r}=0.631 * *$ (Figure 1).

With exception of number of panicles per $\mathrm{m}^{2}$ measured at Fanaye location in rainy season (Table 1), analysis of variance on each site and / or season, combined or not, showed significant effect of genotype on all traits studied. This genotypic variation is an important factor for improving traits (Okeno, 2001).There is also an effect of season on plant duration, and $G \times E$ interaction on plant height, and no effect GxEont grain yield and number of panicles per $\mathrm{m} 2$ (Table 4).

Effect of season on plant duration shows influence of seasonal variations on plant cycle. This result is in accordance with numerous studies on double cropping in Senegal River valley (Dingkuhn and Sow 1995; Dingkuhn M., 1995). During dry season low temperatures in vegetative period have effects on the lengthening of the cycle (Le Gal, 1995). 
Int.J.Curr.Res.Aca.Rev.2016; 4(1): 46-53

Table.1 Average Values Per Season of Traits Studied in Fanaye Location

\begin{tabular}{|c|c|c|}
\hline Traits & Rainy season & Dry season \\
\hline Plant duration (days) & $120,81 *$ & $132,59 * *$ \\
\hline Grain yield $\left(\mathrm{t} \cdot \mathrm{ha}^{-1}\right)$ & $7,41 * *$ & $7,34 * *$ \\
\hline Plant height $(\mathrm{cm})$ & $86,46 * *$ & $91,53 * *$ \\
\hline Paniclenumber $/ \mathrm{m}^{2}$ & $374,87 \mathrm{~ns}$ & $437,96 * *$ \\
\hline
\end{tabular}

**, *,+ : statistically significant difference at $\mathrm{P}=0.01, \mathrm{P}=0.05, \mathrm{P}=0.1$ ANOVA F-test

Table.2 Average Values Per Season of Traits Studied in Ndiaye Location

\begin{tabular}{|c|c|c|}
\hline Traits & Rainyseason & Dry season \\
\hline Plant duration (days) & $115 * *$ & $138,53 * *$ \\
\hline Grain yield (t.ha ${ }^{-1}$ ) & $6,76+$ & $8,09 * *$ \\
\hline Plant height $(\mathrm{cm})$ & $102,01 * *$ & $105,39 * *$ \\
\hline Paniclenumber $/ \mathrm{m}^{2}$ & $346,19 * *$ & $405,61^{*}$ \\
\hline
\end{tabular}

$* *, *,+$ : statistically significant difference at $\mathrm{P}=0.01, \mathrm{P}=0.05, \mathrm{P}=0.1$ ANOVA F-test

Table.3 Average Values of Traits Studied by Season Combined on Both Locations

\begin{tabular}{|c|c|c|}
\hline Traits & Rainyseason & Dry season \\
\hline Plant duration (days) & $117,91 * *$ & $135,56 * *$ \\
\hline Grain yield $\left(\mathrm{t} \cdot \mathrm{ha}^{-1}\right)$ & $7,08 * *$ & $7,72 * *$ \\
\hline Plant height $(\mathrm{cm})$ & $94,24 * *$ & $98,46 * *$ \\
\hline Paniclenumber $/ \mathrm{m}^{2}$ & $360,53 *$ & $421,79 * *$ \\
\hline
\end{tabular}

**, *, +: statistically significant difference at $\mathrm{P}=0.01, \mathrm{P}=0.05, \mathrm{P}=0.1$ ANOVA F-test

Table.4 Average Values of Traits on Both Sites and Both Seasons Combined

\begin{tabular}{|c|c|}
\hline Traits & Average values \\
\hline Plant duration (days) & $126,73 * *$ \\
\hline Grain yield $\left(\mathrm{t} \cdot \mathrm{ha}^{-1}\right)$ & $7,40 * *$ \\
\hline Plant height $(\mathrm{cm})$ & $96,35 * *$ \\
\hline Paniclenumber $/ \mathrm{m}^{2}$ & $391,16 * *$ \\
\hline
\end{tabular}

$* *, *,+$ : statistically significant difference at $\mathrm{P}=0.01, \mathrm{P}=0.05, \mathrm{P}=0.1$ ANOVF-test

Table.5 Values of F of ANOVA of Genotype (G), Location (E), Season (S), and Interactions for Traits Studied

\begin{tabular}{|c|c|c|c|c|c|c|}
\hline Traits & $\mathrm{S}$ & $\mathrm{E}$ & $\mathrm{G}$ & SxG & $E \times G$ & SxExG \\
\hline Plant $\mathrm{c}$ & $2,34 *$ & 1,28 & $15,58 * *$ & 0,34 & $1,43+$ & 0,68 \\
\hline Grain yield (t.ha $\left.{ }^{-1}\right)$ & 0,94 & 1,25 & $2,32 * *$ & 0,82 & 0,61 & $1,42+$ \\
\hline Plant 1 & 1,08 & 1,01 & $10,64 * *$ & 1,07 & $1,79 *$ & 0,91 \\
\hline Paniclenumber $/ \mathrm{m}^{2}$ & 0,78 & 0,67 & $4,32 * *$ & 0,49 & 0,81 & 0,68 \\
\hline
\end{tabular}

**, *,+ : différence statistiquement significatif à $\mathrm{P}=0,01, \mathrm{P}=0,05, \mathrm{P}=0,1$ ANOVA F- test 
Figure.1 Relationship Between Grain Yield and Cycle Length of Lines Studied

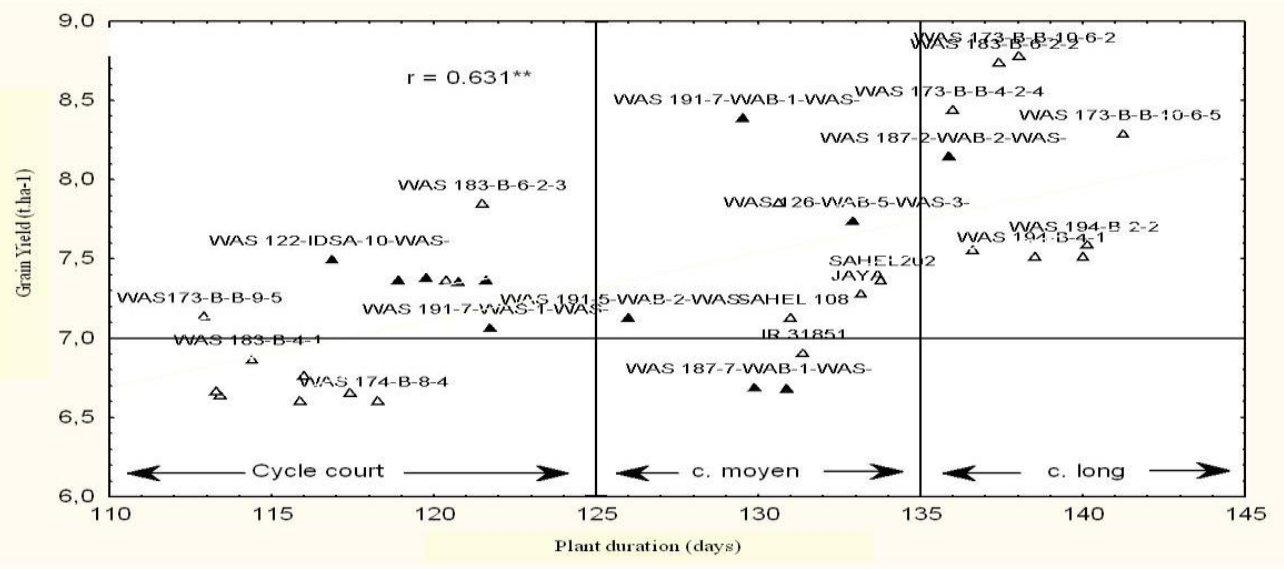

Significant interaction Genotype $\mathrm{x}$ Environment on plant height indicates that variation of sites has an influence on size of lines.

The lack of genotype $\mathrm{x}$ season effects $(\mathrm{G} x$ S) on all traits measured, shows that the seasonal variation does not seem to influence performances of the lines.

Absence of $\mathrm{G} \times \mathrm{E}$ interaction on grain yield is in line with studies on modern varieties characterized by interaction $G \quad x \quad E$ increasingly reduced, and stability increasingly larger (De vita et al. 2010). El Fadil et al., (2014), working on millet in Sudan, has highlighted the importance of the selection of efficient and stable varieties, to impulse programs, and identify interesting genotypes in terms of stability yield, decomposed into two components, a static stability and dynamic stability.

The performance of lines in the sites and seasons combined or not are discriminated lines into three different groups (Table 6), including the lines with good performance across multiple sites and seasons, which are the most interesting. It is a material of choice that has a greater adaptation on all sites and seasons. For better productivity in irrigated rice in the valley, high and stable yields combined with predictable cycles in various environmental conditions in terms of temperature and photoperiod are indeed essential factors (Dingkuhn and Miezan 1992). The varieties and lines that are most successful on one site or one season however, should not be neglected.

Best grain yields on sites and seasons combined were noted in medium duration lines as WAS173-BB-10-6-2 and WAS183B-6-2-2, which belong to the group of highperformance lines at several sites and seasons. Lines that have such characteristics are considered stable lines and are very interesting and well appreciated as these lines can be used in multiple environments. According to Yuan et al., (2011), the best yields are obtained further on lines tested in agronomic disign, as on lines selected according to their agronomic characteristics. These orientations Yuan et al., 2011, are a good source of inspiration to be considered in the process of extension of new varieties.

\section{Conclusion}

The study of agronomic performance of lines from 11 crossings showed promising lines, which can integrate homologation 
process to be released as new varieties. Significant difference of genotype observed at both sites and / or seasons, combined or not, for all variables, allowed to highlight great potential of lines tested. Significant effect of season on plant duration and interaction genotypes $\mathrm{x}$ Site on plant height show importance of external factors like climate, soil, temperature, etc., which affect agronomic performance of lines.

Upon to plant duration, tested lines can be divided into three cycles (short duration, medium duration and long duration). The best grain yields were obtained in medium and long duration lines cycle.

Positive correlation was noted between plant duration and grain yield $(\mathrm{r}=0.631 * *)$. It means that grain yield are a function of the plant duration and best grain yield will be identified in medium to long plant duration varieties and lines. Based on average values of grain yields across sites and seasons combined or not, three categories of lines were observed: (i) lines with good performance across locations and seasons, (ii) lines performing well on one location regardless of season, and (iii) lines performing well on a one season, independently of the locations.

This is a good indication of the rich potential of genetic material studied. Lines of first group, who are performing across locations and seasons, have good ability to double cropping. They should contribute to the improvement of production in the Senegal River valley.

Average yields on locations and seasons combined (6.6 to $8.8 \mathrm{t}$ ha-1) are significant compared to performance obtained in the region. It would be interesting to study performance of these lines on-farm in order to compare performance obtained at experimental research centerswith that obtained in real environment.

This study has shown real potential of interesting lines in the final phase of improvement. Particular attention should be given to this new germplasm whose characteristics favor a better adaptation to environmental condition. It would be interesting to study this material through multi locations trial and on-farm trial. This will help to expand the portfolio of varietal rice grown in the Senegal River Valley and sustainably improve yields by an intensification of double cropping for the benefit of producers and consumers.

\section{References}

Asch F., M. Mingkuhn and Dörfling, K.1995. Physiological stresses of irrigated rice caused by soil salinity in the Sahel. In: Irrigated rice in the Sahel: Prospects for sustainable development. West Africa Rice Development Association (WARDA), pp. 247-273.

Diallo S. and Johnson, D.E. 1995. Les adventices du riz irrigué au Sahel et leur contrôle. In: Irrigated rice in the Sahel: Prospects for sustainable development. West Africa Rice Development Association (WARDA), pp. 311-323.

Dingkuhn M. and Miezan, K. 1992. Temperature related problems in Sahel irrigated rice. West Africa Rice Development Association. 01 BP 2551 Bouaké, Côte d'ivoire. 172 p.

Dingkuhn M. and Miezan, K. 1995. Photothermal adaptations of rice genotypes in the Sahel. In: Irrigated rice in the Sahel: Prospects for sustainable development. West Africa Rice Development Association (WARDA), pp. 327-341. 
Dingkuhn M. and Sow, A. 1995. Potential Yield of irrigated rice in the Sahel. In: Irrigated rice in the Sahel: Prospects for sustainable development. West Africa Rice Development Association (WARDA), pp. 361-379.

Elfadil M.A.B., M.A. Abdelbagi, M.A. Adam, M.I. Ismael, H.K. Parzies, and Haussmann B.I.G.2014. Patterns of pearl millet genotype-by-environment interaction for yield performance and grain iron $(\mathrm{Fe})$ and zinc $(\mathrm{Zn})$ concentrations in Sudan. Field Crops Research, Volume 166, September 2014, Pages 82-91.

$\mathrm{Hu}$ Z., Y. Liu, L.Huang, S.Peng, L.Nie, K.Cui, L.Huang and Wang F. 2015. Premature heading and yield losses caused by prolonged seedling age in double cropping rice. Field Crops Research 183 (2015) 147-155

Jones P. M., M. Dingkuhn, G.K. Aluko et M. Semon, 1997. Interspecific Oryzasativa L. X $O$. glaberrima Steudt. Progenies in upland rice improvement. Euphytica.92 : 327-246.

Le Gal P.Y. 1995. Le dévelopment de la double culture irriguée au Sahel: contraintes et perspectives pour les agriculteurs. In: Irrigated rice in the Sahel: Prospects for sustainable development. West Africa Rice Development Association (WARDA), pp. 161-183.

Li C., Z.Tao, P.Liu, J. Zhang, K. Zhuang, S.Dong and Zhao M. 2015. Increased grain yield with improved photosynthetic characters in modern maize parental lines. Journal of Integrative Agriculture, Volume 14, Issue 9, Pages 1735-1744.

Liang S., G.Ren, J.Liu, X.Zhao, M.Zhou, D.McNeil and Ye G. 2014. Genotypeby-environment interaction is important for grain yield in irrigated lowland rice. Field Crops Research,
Volume 180, Pages 90-99.

Miezan K. and Sié, M.1995. Varietal improvement for irrigated rice in the Sahel. In: Irrigated rice in the Sahel: Prospects for sustainable development. West Africa Rice Development Association, pp 443-455.

Ngam A. O., C. Poisson et A. Sow, 1999. Problématique variétale et filières semencières dans les pays du Pôle Système Irrigués (PSI). In : Pour un dévelopment durable de l'agriculture irriguée dans la zone Soudano Sahélienne. WECARD-CORAF (1999). Pôle Système Irrigué (PSI). 1999

Okeno J.A., 2001. Genotypic variation in morphological traits of barley as affected by nitrogen supply.W.J. Horst et al. (Eds.). Plant nutrition - Food security and sustainability of agroecosystems.Pp. 64-65, 2001 Kluwer Academic Publishers. Printed in the Netherlands.

UTZ H.F., 1997.Ein computerprogramm zur statistischen Analyse von pflanzenzuechterischen Experiment. Version 2B. Institut fuer Pflanzenzuechtung, Saatgutforschung und Populations genetik, Universitaet Hohenheim.

Dingkuhn M., A. Sow, A. Samb, S. Diackand Asch, F.1995. Climatic determinants of irrigated rice performance in the Sahel - I. Photothermal andmicro-climatic responses of flowering. In: agricultural Systen 48 (1995) 385-410

Sie M., Dingkuhnb M., M.C.S. Wopereisa, and Miezana K.M. 1998. Rice crop duration and leaf appearance rate in a variable thermal environment. II. Comparison of genotypes. Field Crops Research 58: 129-140.

Dingkuhn M., Miezan K.M.1995. Climatic determinants of irrigated rice 
performance in the Sahel - II. Validation of photothermal constants and characterization of genotypes. In: agricultural Systen 48 (1995) 411-433.

Vitaa P.D., A.M. Mastrangeloa, L. Matteua, E. Mazzucotellib, N. Virzì, M. Palumboc, M. Lo Stortod, F. Rizzab, and Cattivelli L. 2010. Genetic improvement effects on yield stability in durum wheat genotypes grown in
Italy. Field Crops Research 119 (2010) 68-77.

Yuan W., S. Peng, C. Cao, P. Virk, D. Xing, Y. Zhang, R. M. Visperas and Laza R. C.2011. Agronomic performance of rice breeding lines selected based on plant traits or grain yield. Field Crops Research, Volume 121, Issue 1, vol. 28, 168-174.

\section{How to cite this article:}

Guèye, T., and Saliou, N. 2016. Rice Lines Performance Evaluation under irrigated conditions in the Senegal. Int.J.Curr.Res.Aca.Rev. 4(1): 46-53. doi: http://dx.doi.org/10.20546/ijcrar.2016.401.005 